JOLANTA M. MARSZALSKA

WHNiS UKSW, Warszawa

\title{
INWENTARZE KSIĄG BIBLIOTEKI OPACTWA CYSTERSÓW W SZCZYRZYCU DO KOŃCA XIX WIEKU
}

Pierwsze historycznie potwierdzone wzmianki o bibliotece klasztornej w Szczyrzycu pochodzą z czasów opata Joachima I Cieniawskiego (1592-1607). Za jego rządów klasztor szczyrzycki wizytowany był przez kardynała Jerzego Radziwiłła (1591-1600) w 1597 roku. Zgodnie z nauką Soboru Trydenckiego, biskupi mieli obowiązek szczególnej troski o właściwy poziom intelektualny duchowieństwa diecezjalnego i zakonnego, jego życia religijnego oraz właściwego poziomu umysłowego ${ }^{2}$. Trudno wyobrazić sobie formację religijną bez istotnego elementu służącego do pogłębiania wiedzy, jakim była książka. Na gruncie polskim znajdujemy w drugiej połowie XVI wieku szereg istotnych zaleceń i nakazów, które twórcy ustaw synodalnych odnosili bezpośrednio do książek, ich gromadzenia, przechowywania a nade wszystko wykorzystywania w praktyce ${ }^{3}$.

Pod koniec XVI stulecia w diecezji krakowskiej wizytacją objęte były wszystkie kościoły, zarówno diecezjalne jak i zakonne. Podczas przeprowadzonej wizytacji kardynał Jerzy Radziwiłł zwracał między innymi szczególną uwagę na poziom wykształcenia ówczesnego duchowieństwa (w tym również zakonnego), a także na wyposażenie bibliotek kościelnych, kolegiackich i klasztornych w niezbędne księgi liturgiczne oraz dzieła zawierające treści teologiczne i duchowe. Według zalecenia kardynała:

[...] przy każdym kościele musiały znajdować się następujące księgi: Mszał rzymski, Brewiarz, Antyfonarz, Agenda, Graduale, Konstytucje synodu prowincjalnego gnieźnieńskiego, Katechizm trydencki po tacinie i po polsku, postylle x. Jakuba Wujka T.J po polsku oraz inne potrzebne księgi $[\ldots]^{4}$.

Pod koniec XVI stulecia w klasztorze szczyrzyckim istniał już znacznie rozbudowany księgozbiór, co potwierdzają zapisy w aktach powizytacyjnych ${ }^{5}$. Były to zarówno księgi rękopiśmienne (w tym liturgiczne), a także druki XV-wieczne (inkunabuły) i druki wydane

E. Łużyniecka, J.M. Marszalska, Szczyrzyc. Dzieje budowy opactwa cysterskiego, Wrocław 2005, s. 37-38, 9495; F. Machay, Działalność duszpasterska kardynała Radziwiłta, biskupa krakowskiego 1591-1600, Kraków 1936; R. Raj, Klasztor Matki Boskiej w Szczyrzycu, Arch. i BOCist., bez sygn., s. 86.

2 J. M. Marszalska, Historyczny księgozbiór dawnej biblioteki parafialnej w Pilźnie. Zarys dziejów i stan obecny, w: Dzieje miasta Pilzna, t. 2: Pilzno. Archeologia - Kultura - Społeczeństwo, red. B. Stanaszek, Pilzno 2014, s. 25.

3 Tamże.

4 F. Machay, Działalność duszpasterska kardynała Radziwiłla, biskupa krakowskiego 1591-1600, Kraków 1936, s. $20-21$.

5 Acta Visitationis Archidioecesis Cracoviensis 1727-1742, t. 23, s. 850. 
do 1597 roku, pochodzące z pierwszych europejskich i polskich oficyn typograficznych. Odnotowano następujące księgi, zapisując je jako Libri Ecclesiastici. Były to: [1] Quattuor libri expositionis Lyrae Pomeridana, [2] Bernardus super Cantica, [3] Bernardus de tempore, [4] Summae Angelicae tria volumina, [5] Cathalogi Sanctorum tria volumina, [6] Libri Sanctorum de tempore duo, [7] Liber Cassianus, [8] Sermones de tempore et Sanctis, [9] Liber Contemplatione vitae, [10] Moralia s. Gregorii, [11] Vocabularium, [12] Expositiones Psalmorum, [13] Statuta Carthusianorum, [14] Pissanella Hortulus elegantiarum, [15] Liber de tribus legibus, [16] Speculum exemplorum, [17] Dionisius Carthusianus, [18] Stellarium, [19] Liber homiliarum, [20] Liber sermonum, [21] Missalia octo, [22] Liber lectionum de tempore, [23] Liber lectionum de Sanctis, [24] Gradualia quattuor, [25] Antiphonaria 6, [26] Libri collectorum tres, [27] Libri compendiorum duo, [28] Regula s. Benedicti, [29] Liber definitorum, [30] Liber [...] duo volumina, [31] Bibliorum duo volumina, [32] Liber Evangeliorum et epistolarum, [33] Psalteria quinque, [34] Vitae Christianorum, [35] Tractatus de Sacramentis, [36] Manipulus curatorum, [37] Homiliarum, [38] Liber Lombardica de Sanctis, [39] Historiae Sancti Stanislai, [40] Copiarium Privilegiorum Monasterii ${ }^{6}$.

Zgromadzony księgozbiór pod koniec XVI wieku nie należał do imponujących od strony ilościowej. Nie był spisany, a co więcej kardynał wydał zalecenie opatowi, by: [...] w każdym nowym roku należy nowe książki o treści duchowej zakupić. W tym roku postara się opat Opera Omnia św. Bernarda, Concilium Treidentinum, Cathechismum Romanum, Directorii Palanci pro audiendis confescionibus et per iuramen morientium, Agenda Cassiani I te ksiązki bracia zakonni przy stole zgromadzeni niech czytaja? ${ }^{7}$.

Warto dodać, że wizytujący klasztor - z polecenia kardynała Jerzego Radziwiłła - kanonik Krzysztof Kazimirski, egzaminował również duchownych z elementarnych wiadomości z teologii. W wyniku słabszych odpowiedzi kapłana (w tym też zakonnego) polecał zakupić i studiować dzieło jezuity Jana Polanco, Breve directorium ad conffessarii ac confitentis.., lub dominikanina Marcina Azplicuety, Manuale sive enchiridion conffessariorum ac poenitentium..., niekiedy zaś zalecał katechizm Kanizjusza ${ }^{8}$. Ksiąg tych podczas wizytacji nie stwierdzono na stanie biblioteki opactwa.

Przeprowadzona wizytacja klasztoru szczyrzyckiego w dniach od 13-18 sierpnia 1597 roku, jest znakomitym źródłem pisanym do dziejów klasztoru z końca XVI stulecia. W przypadku biblioteki klasztornej, są to pierwsze historycznie potwierdzone informacje o istnieniu księgozbioru w klasztorze szczyrzyckim. Wśród 40 tytułów ksiąg należy odnotować między innymi sześć antyfonarzy, osiem mszałów, pięć psałterzy, cztery graduały, które bez wątpienia służyły zakonnikom do sprawowania liturgii. Ponadto odnotowano dwa egzemplarze Biblii, homiliarze, kolektarze, żywot św. Stanisława, biskupa i męczennika, regułę św. Benedykta a także Liber Definitorum, czyli księgę uchwał kapituł generalnych cystersów. Uwagę zwracają w pierwszym spisie ksiąg dwa dzieła dotyczące kartuzów, są

\footnotetext{
6 Wśród odnotowanych ksiąg, zachowany był kopiarz przywilejów nadanych klasztorowi, antyfonarze oraz graduały, zdecydowana większość odnotowanych dzieł, to druki XV wieczne, w tym Reguła św. Benedykta z Nursji, dzieła św. Bernarda z Clairvaux, św. Dionizego Kartuza, św. Tomasza z Akwinu, Legenda Lombardica, wokabularze, żywot św. Stanisława bpa i męczennika i inne. Por. J.M. Marszalska, Katalog inkunabułów Biblioteki opactwa oo. cystersów w Szczyrzycu, Kraków 2002, s. 45-80.

7 R. Raj, Klasztor Matki Boskiej w Szczyrzycu, Arch. i BOCist., bez sygn., s. 86.

8 J. M. Marszalska, Historyczny księgozbiór dawnej biblioteki parafialnej w Pilźnie. Zarys dziejów i stan obecny, w: Dzieje miasta Pilzna, t. 2: Pilzno. Archeologia - kultura - społeczeństwo, red. B. Stanaszek, Pilzno 2014, s. 28.
} 
to: Statuta Carthusianorum i bliżej nieokreślone dzieła Dionizego Kartuza. Zakonodawca cystersów - św. Bernard z Clarvaux reprezentowany był zaledwie jednym dziełem Sermones de tempore et de Sanctis et de diversis, wydanym w 1495 roku, w Bazylei i przechowywanym do dnia dzisiejszego ${ }^{9}$, stąd być może zalecenie kardynała, by cystersi szczyrzyccy zakupili Opera omnia św. Bernarda, które winni posiadać w swojej bibliotece. Również dzieła popularnego w swojej epoce Angelusa z Clavasio „Summa Angelica de casibus conscentiae”, było reprezentowane trzema egzemplarzami w bibliotece klasztornej. Zaś „Liber Lombardica de sanctis", to nic innego jak niezwykle popularne dzieło hagiograficzne swojej epoki „Legenda aurea”, Jakuba z Voraginy, wydawane w kilku oficynach europejskich. Wśród ksiąg odnotowanych podczas przeprowadzonej wizytacji w 1597 roku zwraca uwagę „Copiarium Privilegiorum Monasterii”, zwany potocznie kopiarzem dokumentów klasztoru szczyrzyckiego. Nie jest to żaden z zachowanych do dnia dzisiejszego kopiarzy klasztoru, te przechowywane w archiwum szczyrzyckim pochodzą dopiero z I połowy XVII w ${ }^{10}$. Wspomniany, najstarszy kopiarz dokumentów klasztornych nie zachował się do naszych czasów.

Księgi liturgiczne, Pismo św., statuty zakonne, reguła św. Benedykta a także pisma ojców Kościoła, mimo, że gromadzone i przechowywane były głównie z uwagi na „duchową użyteczność", dały z czasem początek zorganizowanej bibliotece klasztornej.

Drugim, ważnym źródłem pisanym - w którym odnotowane zostały informacje dotyczące ksiąg liturgicznych - jest Inventarium Cijrzickiego Kościoła... descriptum vero Anni z $1727^{11}$, który zaczęto spisywać pod koniec rządów opata Mikołaja Romiszowskiego (1684-1727), ukończono zaś za rządów opata Floriana Andrzeja Gotartowskiego (1753-1765). Inwentarz spisywało kilku przeorów konwentu szczyrzyckiego, jednakże największy wkład w dzieło opisu wyposażenia kościoła miał przeor Antoni Stawski, którego nazwisko zostało umieszczone na karcie tytułowej inwentarza ${ }^{12}$. Spisujący majątek kościoła, uwzględnił również księgi liturgiczne, które podzielił na trzy zasadnicze grupy: księgi chóralne, księgi w zakrystii i kanony. Wśród ksiąg chóralnych, przechowywanych zwyczajowo w chórze zakonnym, odnotowane zostały trzy nowe psałterze, jak zapisano: z „okowami mosiężnymi”, w tym dwa psałterze ,antwerpskie”, pięć graduałów w tym jeden graduał ,in folio nowy z okowami mosiężnymi”, pięć antyfonarzy, w tym trzy antyfonarze wykonane na pergaminie, dwa zaś na papierze, dwa hymnarze wykonane ręcznie, dwa procesjonały - w tym jak zaznaczono - ,jeden stary drukowany”, pisanych zaś kilka. Jak zaznaczył spisujący, był też jeden lekcjonarz ,nowy oprawiony i wyzłocony”. W zakrystii kościoła szczyrzyckiego odnotowano również:

\footnotetext{
9 J.M. Marszalska, Katalog inkunabułów Biblioteki Opactwa oo. Cystersów w Szczyrzycu, Tyniec 2002, s. 51, poz. 15.

10 J.M. Marszalska, Najważniejsze źródła rękopiśmienne do dziejów klasztoru oo. Cystersów w Szczyrzycu, „Nasza Przeszłość", 104/2005, s. 37-70.

11 Inventarium Cirzickiego Kościoła omnia ornamenta, in Dei Honorem, Dedicata, Ordine Sequenti in se contens descriptum vero Anno Domini 1727 conscriptus R.P. Antonius Stawski 1728-1740, Arch. i BOCist., bez sygn., s. 49; J.M. Marszalska, Mikołaj Romiszowski profes paradyski, późniejszy opat szczyrzycki w świetle wybranych dokumentów opactwa oo. Cystersów w Szczyrzycu, w: Opactwo cysterskie w Paradyżu. Jego rola w dziejach i kulturze pogranicza, Zielona Góra 2004 s. 73-84; J. M. Marszalska, Opaci komendataryjni wobec książki. Przyczynek do dziejów opactwa Cystersów w Szczyrzycu, w: Klasztor w Państwie średniowiecznym i nowożytnym red. M. Derwich, A. Pobóg - Lenartowicz, Wrocław - Opole - Warszawa 2005.

12 J.M. Marszalska, Najważniejsze źródła rękopiśmienne do dziejów klasztoru oo. Cystersów w Szczyrzycu, „Nasza Przeszłość", 104/2005, s. 67.
} 
[...] Mszat ordinis w czerwonej polyturze z rejestrem czerwonym jedwabnym”, dalej dwa stare mszaty: mszat nowej edycji rzymskiej”, który jak odnotowano ,, [...] sprawit Rev. Nicolaus Romiszowski w safian czerwony oprawiony z pokrowcem skórzanym, z rejestrem jedwabnym czerwonym $[\ldots]^{13}$.

Nadto zostały odnotowane dwa stare mszały rzymskie, cztery mszaliki requialne, stara agenda rzymska, w białej polyturze, jeden pasjonat, oraz brewiarz rzymski stary zapewne zniszczony, gdyż spisujący odnotował, że był w „,złej polyturze”, czyli zniszczonej oprawie.

W pierwszej połowie XVIII wieku, obok wspomnianych mszałów, brewiarzy czy agend, w zakrystii kościoła szczyrzyckiego znajdowały się również trzy kanony, w tym „dwa stare”, oraz jeden - jak odnotowano - kanon nowy rzymski z kopersztychami w politurze safianowej, czerwonej z rejestrem tasiemkowym czerwonym. Był on przechowywany w pokrowcu skórzanym. Kanon został zakupiony dla kościoła szczyrzyckiego przez opata Franciszka Gerarda de Hirtemberg Pastoriusza (1738-1752) ${ }^{14}$.

Do połowy XVIII wieku, nie zachowały się inne źródła pisane odnoszące się do biblioteki klasztornej. Spis ksiąg liturgicznych, który pochodzi z pierwszej połowy XVIII wieku, nie jest odzwierciedleniem zasobności całej biblioteki, gdyż księgi liturgiczne jako niezbędne służyły kapłanom zakonnym do modlitw chórowych i sprawowania liturgii. Ich wykaz sporządzony był w czasie przeprowadzanych wizytacji prowincjalnych bądź generalnych klasztoru oraz kościoła. Jednakże mimo braku źródeł pisanych, fakt istnienia w klasztorze szczyrzyckim zorganizowanej biblioteki nie budzi wątpliwości. Potwierdza to zachowany do czasów współczesnych księgozbiór i jedynie dwie ocalałe karty początkowe najstarszego znanego inwentarza biblioteki, jest to: Cathalogus librorum Monasterij Ciricensis iuxta alphabetum authorum mense Augusto Anno Domini 1755. Conscriptus ${ }^{15}$. Został on sporządzony w okresie rządów w klasztorze opata Floriana Andrzeja Gotartowskiego (1753-1765) ${ }^{16}$. Księgozbiór musiał być znaczny, skoro opat wydał polecenie uporządkowania go i ujęcia w formie katalogu. Jego dokładny opis nie jest możliwy, gdyż do czasów współczesnych zachowały się jedynie dwie początkowe karty obejmujące spis książek w obrębie litery „,A”. Katalog został sporządzony na papierze czerpanym, przez jedną osobę, wskazuje na to identyczny dukt pisma, w wielu miejscach niestaranny. Karty zostały podzielone na kolumny. W środkowej (najszerszej) kolumnie były zapisane nazwiska autorów i tytuły dzieł, w kolumnie po prawej stronie karty - format dzieła. Nie było osobnej kolumny na oznaczenie miejsca i roku wydania w przypadku dzieł drukowanych. Autorzy dzieł, nie byli ujęci w porządku alfabetycznym, np. katalog „rozpoczyna”: Ariosto Alexander z dziełem Enchiridion, zaś kilka linijek poniżej został zapisany Alciatus, czy Acta Synodu gnieźnieńskiego itd. W spisie (w obrębie litery „A”) nie zastosowano wydzielenia formatów, formaty in folio, in quarto i octavo i in duodecimo zostały przemieszane ${ }^{17}$.

13 Inventarium Cirzickiego Kościoła [...], Arch. i BOCist., bez sygn., s. 49.

14 J.M. Marszalska, W. Graczyk, Opaci i przeorzy klasztoru oo. cystersów w Szczyrzycu od XIII do XX wieku, Tyniec 2006, s. 155- 162 .

15 Cathalogus librorum Monasterij Ciricensis iuxta alphabetum authorum mense Augusto Anno Domini 1755. Conscriptus, Arch. i BOCist., bez sygn.

16 J.M. Marszalska, W. Graczyk, Opaci i przeorzy klasztoru oo. cystersów w Szczyrzycu od XIII do XX wieku, Tyniec 2006, s.163-169.

17 Prawdopodobnie zamierzeniem spisującego było stworzenie katalogu biblioteki a nie inwentarza co często bywa utożsamiane. Zasadnicza cecha bowiem jaka odróżnia katalog od inwentarza tkwi w odmiennych zadaniach 
Od strony opisu bibliograficznego poszczególnych dzieł „Cathalogus librorum Monasterij Ciricensis” nie prezentuje wysokiego poziomu „umiejętności bibliotekarskich”. Jest to zjawisko dość charakterystyczne dla wielu spisów ksiąg klasztornych z XVIII wieku. Zastosowany opis ksiąg jest lakoniczny, ograniczony jedynie do podania imienia i nazwiska autora, oraz kilku wyrazów tytułu. Tytuły dzieł zostały skrócone według własnych ustaleń spisującego księgi zakonnika, np.”Paradoxa, Abecadarium liber”,czy „,Axiomata chrześcijańskiej filozofii”. Katalog z 1755 roku, spisywany był w języku łacińskim, tylko przy jednym tytule zastosowano język polski, jest to: „Summariusz osób Świątobliwych Zakonu O.S. Benedykta X. Wegrzynowicza”. Przy żadnym z opisywanych dzieł nie podano miejsca, roku wydania ani oficyny wydawniczej. Nie podano też sygnatury miejsca książki na półce. Zachowane dwie karty katalogu obejmują łącznie 46 pozycji bibliograficznych i nie mogą być reprezentatywne dla określenia zasobności biblioteki szczyrzyckiej w pierwszej połowie XVIII wieku.

Inwentarzem sensu stricto obejmującym całość zasobów biblioteki klasztoru szczyrzyckiego jest dopiero inwentarz pochodzący z 1826 roku, sporządzony na polecenie władz guberni austriackiej, w okresie tzw. ,,przeoratu szczyrzyckiego"(1794-1918) ${ }^{18}$. W tym czasie została przeprowadzona dwukrotnie inwentaryzacja obejmująca kościół, klauzurę, zabudowania gospodarcze klasztoru, całe wyposażenie zakrystii kościelnej. Spisowi podlegały również książki znajdujące się w bibliotece klasztornej. Obecnie w archiwum klasztoru cystersów w Szczyrzycu przechowywane są cztery odpisy wspomnianego inwentarza z 1826 roku. Trzy z nich mają charakter odrębnych poszytów, zaś czwarty został dołączony do ogólnego inwentarza klasztoru szczyrzyckiego. Został on sporządzony w 1827 roku za rządów przeora Gerarda Zimowskiego (1823-1834) ${ }^{19}$ i nosi on tytuł: Inventarium Klosters zu Szczyrzyce aufgenommen in Folge hoher Gub. Verordnung von 13 Juny 826 durch den Kreiskommisar von Karchesy mit Zuziehung des Tymbarker lat. Dechant Daneck am 26 August bis 8 - ten September, dann am 23 September bis 30 October des Jahres $1827^{20}$.

Zachowany inwentarz księgozbioru klasztornego zawiera następujące działy: Biblia Sacra - 16 vol., Commentarii - 26 vol., Opera Patrum - 40 vol., Theologi morales - 118 vol., Dogmatici - 26 vol., Vitae Patrum Sanctorum - 37 vol., Concionatores latini - 167 vol., Kazania polskie - 113 vol., Panegirici - 26 vol. Libri religiosorum - 44 vol. Iura canonica - 60 vol., Iura civila - 40 vol. Historicii - 111 vol. Libri controversii - 84 vol., Philosophi - 36 vol.,

\footnotetext{
obu spisów. Katalog służy do udostępnienia księgozbioru, wskazuje przy tym miejsce przechowywania określonego tytułu, inwentarz ma przede wszystkim na celu ustalenie stanu majątkowego danej instytucji w zakresie posiadanych przez nią zbiorów. Por. J. Grycz, „Bibliotekarstwo praktyczne”, Warszawa 1945, s. 71, A. Więckowska, H. Pliszczyńska, „Podręczny słownik bibliotekarza”, Warszawa 1955, s. 88.

18 J.M. Marszalska, W. Graczyk, Opaci i przeorzy klasztoru oo. cystersów w Szczyrzycu od XIII do XX wieku, Tyniec 2006, s.181-217.

19 J.M. Marszalska, W. Graczyk, Opaci i przeorzy klasztoru oo. Cystersów w Szczyrzycu od XIII do XX wieku,... s. 193-195.

20 Inventarium Klosters zu Szczyrzyce aufgenommen in Folge hoher Gub. Verordnung von 13 Juny 826 durch den Kreiskommisar von Karchesy mit Zuziehung des Tymbarker lat. Dechant Daneck am 26 August bis 8 - ten September, dann am 23 September bis 30 October des Jahres 1827, Arch. i BOCist., bez sygn.; W. Jabłońska, "Inwentarze i katalogi biblioteczne w zbiorach rękopiśmiennych Biblioteki Zaktadu Narodowego im. Ossolińskich, w: Ze skarbca Kultury. Biuletyn Informatyczny ZniO, 20/1969, s. 104-105.
} 
Rethores - 71 vol., Poetae - 41 vol., Grammatici - 21 vol., Geographi, Medici, Astronomi et Mathematici - 25 vol., Politici - 31 vol., Ascetae - 348 vol. ${ }^{21}$

Inwentarz spisano na papierze czerpanym przez jedna osobę, o czym świadczy identyczny dukt pisma na wszystkich kartach. Całość nie posiada żadnej zabezpieczającej oprawy. Karty inwentarza zostały zszyte cienkim sznurkiem na grzbiecie. Inwentarz został podzielony na rubryki: po lewej stronie karty, wyszczególnione zostały dwie kolumny w obrębie których zastosowano:

a) numerację ciągłą dla wszystkich dzieł obejmujących wszystkie działy

b) numerację osobną dzieł w obrębie działu.

Środkową kolumnę przeznaczono na opis dzieła $\mathrm{z}$ podaniem autora i tytułu, w prawej kolumnie odnotowano miejsce wydania (locus editionis), rok wydania (annus editionis),w pozostałych kolumnach zapisano formaty książek: in folio, in quarto, in octo, in duodecimo, in sextodecimo.

W inwentarzu odnotowano łącznie 1513 dzieł, niestety nie da się jednoznacznie i precyzyjnie określić ilości voluminów a także potwierdzić, ile spisanych ksiąg to inkunabuły, gdyż zaledwie przy 10 drukach piętnastowiecznych została podana pełna data ich wydania.

W wielu przypadkach spisujący księgi klasztorne obok imienia i nazwiska autora (bądź samego nazwiska), zapisał jedynie miejsce i rok wydania, pomijając tytuł dzieła. Są też i przypadki odwrotne, gdzie przy opisach wielu dzieł podano ich tytuł, nie odnotowując miejsca i roku wydania. Przy żadnym zapisie nie podano oficyny wydawniczej. Forma zapisu księgi w inwentarzu, świadczy o pewnej niedbałości, niefachowości i pośpiechu spisującego księgi klasztorne. Gdzieniegdzie przy opisie książki (przy kilku tytułach) umieszczono notkę: dziełko doskonałe. Fakt ten świadczy o znajomości treści książki przez spisującego księgi biblioteki szczyrzyckiej. W dalszej kolejności księgozbiór klasztorny podzielono na działy, w obrębie których spisano poszczególne dzieła, bez zastosowania układu alfabetycznego w obrębie tytułów bądź autorów poszczególnych dzieł. Nie umieszczono też żadnej wzmianki o nadaniu sygnatury miejsca poszczególnym voluminom.

Zasadniczo wszystkie cztery katalogi z 1826 roku, zawierają te same działy z wyjątkiem jednego spisu, w którym nie odnotowano działu libri prohibita. Jak wynika z porównania katalogów z 1826 roku, liczba ujętych w spisie ksiąg jest zasadniczo identyczna. Różnica ilościowa dotyczy tylko ksiąg z tematyki ascetycznej, w jednym z inwentarzy ujęto 348 vol. pod hasłem Ascetae, zaś w innym 374 vol. A zatem widoczna jest różnica 26 voluminów, co mogło być wynikiem pomyłki przepisującego. Nadto w jednym z katalogów z 1826 roku, w obrębie działu grupującego księgi o tematyce ascetycznej, na końcu dopisano dzieła wydane w 1864 roku. Zapewne zapis uczyniono później w formie uzupełnienia. Tak sporządzony katalog biblioteki klasztoru szczyrzyckiego daleki był od zasad obowiązujących przy właściwym i poprawnym opisie dzieła. Spisujący księgi miał przede wszystkim na uwadze wykazanie ilościowe dzieł, istotnych przy inwentaryzacji całego majątku klasztornego. Szczególnie, że w pierwszej połowie XIX wieku, całe mienie zakonów (a w ich obrębie klasztorów) podlegało obowiązkowej inwentaryzacji, zarządzonej przez austriackie władze

21 Inventarium Klosters zu Szczyrzyce aufgenommen in Folge hoher Gub. Verordnung von 13 Juny 826 durch den Kreiskommisar von Karchesy mit Zuziehung des Tymbarker lat. Dechant Daneck am 26 August bis 8 - ten September, dann am 23 September bis 30 October des Jahres 1827, Arch. i BOCist., bez sygn., k. 9v-22v. 
zaborcze. Dotyczyło to również klasztorów, które nie uległy kasacie. Do takich należało opactwo cystersów w Szczyrzycu czy klasztor karmelitów bosych w Czernej.

U schyłku lat 60. XIX stulecia na polecenie władz austriackich został przeprowadzony kolejny spis majątku klasztoru szczyrzyckiego. Miał on miejsce w okresie rządów przeorskich Wincentego Wojciecha Kolora (1869-1905)22. Inwentaryzacji podlegały w całości zabudowania klasztorne oraz gospodarcze, wyposażenie kościoła oraz zakrystii kościelnej. Spisowi podlegały też wszystkie dokumenty pergaminowe w tym przywileje i nadania królów polskich i książąt na przestrzeni kilku wieków dla klasztoru, nadto księgi i paramenty liturgiczne będące na wyposażeniu zakrystii oraz biblioteka klasztorna. Z tego też okresu zachował się bardzo szczegółowy opis zabudowań klasztornych, będący nieocenionym źródłem do badań nad klasztorem u schyłku XIX w ${ }^{23}$.

Kolejny, trzeci inwentarz klasztoru szczyrzyckiego zatytułowany został: Inwentarz klasztoru męskiego Księży Cystersów w Szczyrzycu, Diecezji Tarnowskiej a Starostwa Limanowskiego w Galicji na wskutek rozporzadzenia wysokiego C.K. Namiestnictwa we Lwowie z dnia 20 II 1868, za L.: 6285 I 4 -stycznia 1869 za L.: $68026^{24}$. Jest to księga oprawiona w twardą oprawę tekturową. Opis majątku kościelnego i klasztornego poprzedzony został wstępem historycznym dotyczącym fundacji klasztoru i jego dziejów. Na stronach 57 do 97 zostały spisane księgi liturgiczne, znajdujące się w zakrystii kościelnej oraz całość zasobów biblioteki klasztornej. Spisujący księgi liturgiczne zastosował określenie: Księgi ściśle liturgiczne, w obrębie których odnotowano m. in. mszały, w tym mszały żałobne pro defunctis, $w$ skóre oprawne nie okute, dziwięć psalterzy w skórę oprawnych i po rogach mosiężnych okute”25. „canon Abbatiale”, „Antyfonarz w skórę oprwany”, dalej ,,cztery książki Agendy w skórę oprawione; dwie ewangelie w zwykłej oprawie, dwanaście brewiarzy w skórę oprawnych, każdy po dwa tomy ${ }^{26}$.

Obok tytułów ksiąg liturgicznych, zamieszczona została informacja o wartości materialnej księgi w złp a także szczegółowa informacja, z której wynika, że spisujący księgi zakrystii szczyrzyckiej porównywał ilość ksiąg przez siebie spisywanych w latach 60. XIX wieku, do spisu inwentarzowego z 1827 roku, odnotowując między innymi:

[...] 2 mszałów wspomnianych $w$ dawnym inwentarzu, pod poz. 67, ubyt jeden, a z mszałów wspomnianych pod poz. 168 ubyto cztery, wreszcie z 11 psatterzy zapisanych w tym inwentarzu pod poz. 176 ubyto dwa, zaś księgi zapisane w tym inwentarzu pod poz. 172, 173, 174 i 175 popadly z biegiem czasu w zniszczenie i zostaly zupetnie usunięte $e^{27}$.

Obok ksiąg liturgicznych spisano również księgi metrykalne znajdujące się w tym czasie w szafach zakrystii kościoła szczyrzyckiego, w tym:

\footnotetext{
22 J.M. Marszalska, W. Graczyk, Opaci i przeorzy klasztoru oo. Cystersów w Szczyrzycu od XIII do XX wieku..., s. 204-207.

23 E. Łużyniecka, J.M. Marszalska, Szczyrzyc. Dzieje budowy opactwa cysterskiego. Wrocław 2005, s. 118-138.

24 Inwentarz klasztoru męskiego Księży Cystersów w Szczyrzycu, Diecezji Tarnowskiej a Starostwa Limanowskiego w Galicji na wskutek rozporzadzenia wysokiego C.K. Namiestnictwa we Lwowie z dnia 20 II 1868, za L.: 6285 I 4 -stycznia 1869 za L.: 68026, Arch. i BOCist., bez sygn.

25 Inwentarz klasztoru męskiego Księży Cystersów w Szczyrzycu z 1869 r., Arch. i BOCist., bez sygn., s. 57.

26 Inwentarz klasztoru męskiego Księży Cystersów w Szczyrzycu z 1869 r., Arch. i BOCist., bez sygn., s. 57v.

27 Inwentarz klasztoru męskiego Księży Cystersów w Szczyrzycu z 1869 r., Arch. i BOCist., bez sygn., s. 57.
} 
Metryka urodzonych $w$ obcych parafiach a $w$ Szczyrzycu chowanych, poczynajac od roku 1859”, trzy tomy indeksów do powyższych ksiag metrtykalnych, poczawszy od roku 1786, dalej dwa tomu Examen sponsorum, od 1845 r., ksiegga zapowiedzi od roku 1854, książa członków towarzystwa wstrzęmieźliwości, sześć metryk „,natorum, copulatorum i mortuorum” dla gminy Jodłownik, Kostrza-Ryje, począwszy od roku 1786 i ponownie od roku 1852

Księgi metrykalne po raz pierwszy zostały ujęte w spisie inwentarza w 1869 roku, z uwagi na powstanie parafii w Szczyrzycu ${ }^{28}$. Z oczywistych względów przy księgach parafialnych nie odnotowano ich wartości materialnej, tak jak miało to miejsce przy księgach liturgicznych, Ksiag zapisanych powyżej po pozycją nr 12 aż do 21 - nie oceniono jako ksiąg ściśle urzędowych ${ }^{29}$.

Spis książek znajdujących się w bibliotece klasztornej w drugiej połowie XIX wieku umieszczony został w inwentarzu na stronach 59-97. Księgi spisane były - podobnie jak cały inwentarz - przez jedną osobę. Karty inwentarza podzielone zostały na rubryki, po lewej stronie karty wyszczególnione zostały kolumny z podaniem liczby porządkowej w obrębie której wyszczególniono liczbę bieżącą (nowego inwentarza) oraz liczbę dawnego inwentarza, dalej następował opis tytułu książki, nazwiska i imienia autora, po prawej stronie karty odnotowane zostały kolumny, w których uwzględniony został opis wydawniczy książki w tym: miejsce i rok wydania, dalej następowało wyszczególnienie formatów książek: in folio, in 4-o, in 8-vo, in 12 - cimo, in 16 -decimo, w ostatniej rubryce odnotowano zapis: wartość w walucie austr. lub polskiej, której zresztą nie wypełniano.

Całość zasobu biblioteki klasztornej została podzielona na działy tematyczne, podobnie jak w inwentarzu z 1826 roku, zastosowany układ był identyczny.

Spisujący księgi odnotowat: Biblia Sacra - 16 vol., Commentarii - 26 vol., Opera Patrum - 40 vol., Theologi morales - 73 vol., Dogmatici - 26 vol., Vitae Patrum Sanctorum 37 vol., Concionatores latini - 167 vol., Kazania polskie - 113 vol., Panegirici - 25 vol., Libri religiosorum -44 vol. Iura canonica -60 vol., Iura civila -40 vol. Historicii -111 vol. Libri controversii - 84 vol., Philosophi - 36 vol., Rethores - 71 vol., Poetae - 40 vol., Grammatici - 21 vol., Geographi, Medici, Astronomi et Mathematici - 25 vol., Politici - 31 vol., Ascetae - 379 vol.

Całość zasobu biblioteki spisano w poszczególnych działach bez zastosowania układu alfabetycznego w obrębie tytułów bądź autorów poszczególnych dzieł. Przy większości dzieł odnotowano miejsce i rok wydania książki bez uwzględnienia oficyny wydawniczej, a także format dzieła, zaś ostatnia kolumna, w której zwykło się podawać wartość książki pozostała niewypełniona. Pod pozycją inwentarza: 1480 odnotowano: „Oprócz dziet powyższych sprawit konwent własnym kosztem $i$ w ten sposób przybyło do biblioteki" i tu następuje wyliczenie 30 dzieł, które zostały zakupione przez konwent szczyrzycki na przestrzeni 40 lat począwszy od 1826 roku. Temu lakonicznemu stwierdzeniu przeczy porównanie obu

28 Cystersi prowadzili parafię od początku fundacji, pierwsza wzmianka pochodzi z 1238 r.; w 1244 parafię przejęli cystersi z Ludźmierza; w 1298 r. parafię zniesiono i jako filię przyłączono do Góry św. Jana; w 1798 r. bp tarnowski Florian Amand Janowski zniósł parafię w Górze św. Jana i na prawach filii przyłączył ją do wznowionej parafii w Szczyrzycu; najstarsza księga metrykalna pochodzi z 1790 r. Najstarsze księgi metrykalne przechowywane są w Archiwum klasztornym w Szczyrzycu. Por. Schematyzm Diecezji tarnowskiej, Tarnów 1977, s. 507.

29 Inwentarz klasztoru męskiego Księży Cystersów w Szczyrzycu z 1869 r., Arch. i BOCist., bez sygn., s. 57v. 
inwentarzy bibliotecznych z 1826 i 1869 roku, z którego wynika, że widoczne są zmiany w dwóch działach ksiąg. Otóż w obrębie ksiąg o tematyce ascetycznej w 1826 roku odnotowano 374 voluminów, zaś w inwentarzu z 1869 roku - 379 voluminów, a więc zaledwie o 5 tytułów więcej. Zasadnicza różnica widoczna jest w dziale grupującym książki z zakresu teologii moralnej. W tym przypadku sytuacja jest odwrotna. W 1826 roku, zapisano w inwentarzu 118 voluminów z tej tematyki, zaś w inwentarzu z 1869 roku, już tylko 73 voluminuy. Być może widoczna różnica 45 voluminów, które były na stanie biblioteki klasztornej w 1826 roku, a których nie ujęto w spisie w 1869, mogła być m. in. podyktowana wycofaniem niektórych ksiąg z użytkowania, bądź ich zniszczeniem. Zawartość ilościowa pozostałych działów ksiąg w obu inwentarzach jest identyczna. Zatem stan ilościowy księgozbioru klasztornego zarówno w pierwszej jak i w drugiej połowie XIX stulecia niewiele się różnił. Układ działów również był identyczny. Można wysunąć wniosek, iż biblioteka, mimo że liczyła ponad 1500 voluminów, faktycznie nie wykazywała tendencji rozwojowej. Świadczą o tym nieuzupełniane zbiory ksiąg prawie we wszystkich działach. Taka sytuacja była podyktowana $\mathrm{m}$. in. trudną sytuacją ekonomiczną klasztoru, jak również małym zainteresowaniem potrzebami intelektualno-duchowymi niewielkiego konwentu, dla którego istotniejsza była potrzeba przetrwania ekonomicznego niż rozwój intelektualno-duchowy. Nadto trudny czas tzw. "przeoratu", klasztoru szczyrzyckiego przypadający na lata zaborów (1794 - 1918), nie sprzyjał powiększaniu zasobów bibliotecznych, a wręcz przeciwnie, dzięki licznie odbywanym w tym czasie podróżom historyczno geograficznych po Galicji dochodziło do uszczuplenia wielu księgozbiorów zakonnych. Klasztor szczyrzycki już wówczas określany był jako „wielce starożytny” i pełen pamiątek przeszłości. W 1849 roku, klasztor w Szczyrzycu został odwiedzony przez historyków krakowskich, Józefa Jerzmanowskiego i Józefa Łepkowskiego. Podróżnicy zamieścili nieco później opis opactwa i jego biblioteki w artykule opublikowanym w „Bibliotece Warszawskiej” zatytułowanym „Ułamek z podróży archeologicznej po Galicji odbytej w roku 1849", gdzie zapisano:

[...] z dawnego archiwum klasztoru szczyrzyckiego niewiele zostało, a biblioteka bardzo ucierpiała, gdyż w roku 1794 rękopisy i znaczna część druków wywieziono do Lwowa i wcielono wraz z innymi po zniesionych w catym kraju klasztorach do biblioteki uniwersyteckiej, gdzie podczas pożaru w r. 1848 spłonęty. Część biblioteki przewieziono do tarnowskiego seminarium duchownego ${ }^{30}$.

Informacja dotycząca losów biblioteki szczyrzyckiej po 1794 roku, którą obaj uczeni zamieścili na łamach czasopisma „Biblioteka Warszawska” jest nieprawdziwa. Otóż na podstawie przeprowadzonych badań zachowanych dokumentów z konsystorza biskupiego w Tarnowie, nie ma podstawy źródłowej, by stwierdzić przejęcie części biblioteki szczyrzyckiej (w tym rękopisów) przez bibliotekę Seminarium Duchownego w Tarnowie. Przemawiają za tym stwierdzeniem fakty historyczne. Otóż w 1794 roku, kiedy to księgi szczyrzyckie miały ,jakoby trafić” do biblioteki tarnowskiego seminarium, gmach seminarium jeszcze nie istniał. Tym bardziej nie mogła istnieć biblioteka seminaryjna. Nieudokumentowana pozostaje także informacja o przewiezieniu biblioteki szczyrzyckiej po 1794 roku do Lwowa. Twierdzenie takie jest mało wiarygodne. Nie wzmiankuje o obecności ksiąg szczyrzyckich

30 J. Łepkowski, J. Jerzmanowski, „Ułamek z podróży po Galicji odbytej w roku 1849”, „Biblioteka Warszawska”, 3/1850, s. 193 -224; Sprawę rzekomego przewiezienia zbiorów biblioteki szczyrzyckiej do seminarium tarnowskiego wyjaśniła w oparciu o badania archiwalne J.M. Marszalska w publikacji dotyczącej biblioteki klasztoru, pt. „Biblioteka opactwa cystersów w Szczyrzycu do końca XIX stulecia. Dziedzictwo wieków”. Tarnów 2007, s. 64-65. 
w zbiorach Biblioteki Uniwersytetu Lwowskiego - jak było to choćby w przypadku biblioteki tynieckiej - opracowanie Ludwika Finkla i Stanisława Starzyńskiego ${ }^{31}$. Zbiory Biblioteki Uniwersyteckiej lwowskiej i istniejących już bibliotek seminaryjnych były „zasilane” przez księgi ze skasowanych klasztorów z terenu Galicji. Klasztor cystersów w Szczyrzycu w 1794 roku, stracił jedynie status opactwa i funkcjonował nieprzerwanie jako przeorat do 1918 roku, nigdy nie podlegając kasacie. A zatem uszczuplenie zbiorów biblioteki klasztornej, szczególnie jeśli chodzi o kodeksy rękopiśmienne należy upatrywać między innymi w zainteresowaniach kolekcjonerskich wielu wybitnych polskich uczonych, antykwariuszy a nawet zwyczajnych handlarzy. Klasztor zaś w pierwszej połowie XIX wieku (naznaczony licznymi klęskami żywiołowymi) z trudem pokonywał codzienność, zmagając się często z widmem głodu, zarazy i braku pieniędzy na bieżące potrzeby. Zachowane XIX wieczne inwentarze klasztorne, w których ujęto również zgromadzone przed wiekami księgi, są odzwierciedleniem stanu i zasobności klasztoru w dobra ruchome i nieruchome w trudnym okresie przetrwania, jakim był przeorat.

\section{The inventory of the books of the Abbey library of Cistercians in Szczyrzyc to the end of nineteenth century \\ Summary}

The first historically confirmed records of the library of Szczyrzyc monastery are from the time of abbot Joahim I Cieniawski (1592-1607). Among the 40 titles of books recorded during the visitation in 1597 was: six antiphonals, eight missals, five psalters, four graduals, two copies of the Bible, homiliarz, kolektarz, the life of St. Stanislaus bishop and martyr, the St. Benedict's rule and also Liber Definitorum, which is the book of the resolution of the General Chapters of the Cistercian. The first catalogue of books was made in 1755 and was entitled Cathalogus librorum Monasterij Ciricensis iuxta alphabetum authorum mense Augusto Anno Domini 1755. Conscriptus. It is a pity that only two initials cards including a list of books within the letter "A" were preserved until modern times. Three nineteenth century inventories provide full knowledge about this collection of books taking into account the title of a book, the author's name, the description of a book (place and year of publication) and format of a book. The person who wrote the book made their thematic segregation. Undoubtedly the number of books, titles and in particular the authors demonstrate the need and the importance which the Szczyrzyc monastery given to the books which reading had to help the monk in his pilgrimage to God.

Keywords: monastery, Cistercian, books, Szczyrzyc, inventory

Nota o Autorze: prof. zw. dr hab. Jolanta M. Marszalska - profesor zwyczajny w Instytucie Nauk Historycznych Wydziału Nauk Historycznych i Społecznych Uniwersytetu Kardynała Stefana Wyszyńskiego w Warszawie. Prowadzi badania nad staropolska kulturą piśmiennictwa, monastycyzmem, księgozbiorami klasztornymi: benedyktynów, cystersów, bernardynów i karmelitów bosych, historycznymi księgozbiorami diecezji tarnowskiej i płockiej oraz księgozbiorami i dziejami rodów magnackich.

31 L. Finkiel, S. Starzyński, Historia Uniwersytetu Lwowskiego, Lwów 1894. 